\title{
$\alpha$-Globin genes: thalassemic and structural alterations in a Brazilian population
}

M.R.S.C. Wenning ${ }^{1}$,

E.M. Kimura ${ }^{1}$, F.F. Costa²,

S.T.O. Saad², S. Gervásio',

S.B. de Jorge ${ }^{1}$, E. Borges $^{1}$,

N.M. Silva ${ }^{1}$ and

M.F. Sonati ${ }^{1}$
Departamentos de ${ }^{1}$ Patologia Clínica and

${ }^{2}$ Clínica Médica, Faculdade de Ciências Médicas,

Universidade Estadual de Campinas,

Campinas, SP, Brasil

\section{Correspondence}

M.F. Sonati

Departamento de Patologia Clínica

FCM, UNICAMP

Caixa Postal 6111

13083-970 Campinas, SP

Brasil

Fax: + 55-19-289-3273

E-mail: sonati@fcm.unicamp.br

Research supported by FAPESP (No. 96/1118-8 and No. 97/11725-1) and CNPq (No. 520059/95-6).

Received December 17, 1999 Accepted July 6, 2000

\section{Abstract}

Seven unrelated patients with hemoglobin $(\mathrm{Hb}) \mathrm{H}$ disease and 27 individuals with $\alpha$-chain structural alterations were studied to identify the $\alpha$-globin gene mutations present in the population of Southeast Brazil. The - $\alpha^{3.7}$,--MED and - $(\alpha)^{20.5}$ deletions were investigated by PCR, whereas non-deletional $\alpha$-thalassemia $\left(\alpha^{\mathrm{Hph}} \alpha, \alpha^{\mathrm{NcoI}} \alpha, \alpha \alpha^{\mathrm{NcoI}}, \alpha^{\mathrm{Ic}} \alpha\right.$ and $\alpha^{\text {TSaudi }} \alpha$ ) was screened with restriction enzymes and by nested PCR. Structural alterations were identified by direct DNA sequencing. Of the seven patients with $\mathrm{Hb} \mathrm{H}$ disease, all of Italian descent, two had the $-(\alpha)^{20.5} /-\alpha^{3.7}$ genotype, one had the --MED/- $\alpha^{3.7}$ genotype, one had the $-{ }^{\mathrm{MED}} / \alpha^{\mathrm{Hph}} \alpha$ genotype and three showed interaction of the $-\alpha^{3.7}$ deletion with an unusual, unidentified form of non-deletional $\alpha$ thalassemia $\left[-\alpha^{3.7} /(\alpha \alpha)^{\mathrm{T}}\right]$. Among the 27 patients with structural alterations, 15 (of Italian descent) had $\mathrm{Hb}$ Hasharon $(\alpha 47 \mathrm{Asp} \rightarrow$ His) associated with the $-\alpha^{3.7}$ deletion, 4 (of Italian descent) were heterozygous for Hb J-Rovigo ( $\alpha 53 \mathrm{Ala} \rightarrow$ Asp), 4 (3 Blacks and 1 Caucasian) were heterozygous for $\mathrm{Hb}$ Stanleyville-II ( $\alpha 78 \mathrm{Asn} \rightarrow$ Lys) associated with the $\alpha^{+}$-thalassemia, 1 (Black) was heterozygous for $\mathrm{Hb}$ G-Pest $(\alpha 74$ Asp $\rightarrow$ Asn), 1 (Caucasian) was heterozygous for Hb Kurosaki $(\alpha 7 \mathrm{Lys} \rightarrow \mathrm{Glu}), 1$ (Caucasian) was heterozygous for $\mathrm{Hb}$ Westmead $(\alpha 122 \mathrm{His} \rightarrow \mathrm{Gln})$, and 1 (Caucasian) was the carrier of a novel silent variant (Hb Campinas, $\alpha 26 \mathrm{Ala} \rightarrow \mathrm{Val}$ ). Most of the mutations found reflected the Mediterranean and African origins of the population. Hbs G-Pest and Kurosaki, very rare, and Hb Westmead, common in southern China, were initially described in individuals of ethnic origin differing from those of the carriers reported in the present study and are the first cases to be reported in the Brazilian population.

\section{Key words}

- $\alpha$-Globin genes

- $\alpha$-Globin structural variants

- $\alpha$-Thalassemia

- Hemoglobin $\mathrm{H}$

- $\mathrm{Hb} \mathrm{H}$ disease

- Hemoglobin variants

- Hemoglobinopathies

\section{Introduction}

The hemoglobinopathies are a heterogeneous group of genetic disorders caused by mutations affecting the globin-chain genes. Generically, these mutations can be classified as structural alterations which result in the production of abnormal proteins, as al- terations in synthesis which modify the normal $\alpha / \beta$ globin chain ratio (thalassemias), or as persistent production of fetal hemoglobin $\mathrm{Hb}$ ) during adult life (hereditary persistence of fetal $\mathrm{Hb}$ ) $(1,2)$. The hemoglobinopathies represent a public health problem, particularly in the Mediterranean area, in the Middle East and in parts of India, Africa and South- 
east Asia $(3,4)$.

The high degree of racial admixture among native Indians and African and European descendants in the Brazilian population has produced elevated frequencies of $\mathrm{Hb}$ alterations, which reflect the diversity of racial origins in each region of the country (5). Clinically, $\mathrm{Hb} \mathrm{S}, \mathrm{Hb} \mathrm{C}$ and B-thalassemia are the most important (6), although $\alpha^{+}$-thalassemia ( $-\alpha^{3.7}$ deletion) is the most frequent alteration, occurring in $20-25 \%$ of the Black population (7). Although sporadic cases of $\mathrm{Hb} \mathrm{H}$ disease and $\alpha$-chain structural variants have been found $(6,8)$, the $\alpha$-globin genes have not been systematically investigated. In this study, seven unrelated subjects with $\mathrm{Hb} \mathrm{H}$ disease and 27 individuals with structural $\alpha$-globin alterations were investigated in order to identify the mutations present in the population of southeastern Brazil. $\mathrm{The} \mathrm{Hb} \mathrm{H}$ disease patients and the carriers of abnormal Hbs who had hematological alterations were initially screened at the outpatient clinics of the UNICAMP University Hospital and then referred to the Clinical Pathology Laboratory for investigation and diagnosis. Non-symptomatic carriers were detected in a screening program carried out in the same laboratory.

\section{Material and Methods}

Peripheral blood samples were collected into Vacutainers (Becton-Dickinson, Corkeysville, MD, USA) with EDTA as anticoagulant and hematological data were obtained with an automated cell counter (Cell Dyn 3500, Abbott Laboratories, Chicago, IL, USA).

$\mathrm{Hb}$ analyses were carried out by electrophoresis on cellulose acetate strips at $\mathrm{pH} 8.9$, in agar gels at $\mathrm{pH} 6.0$ (1), and by globin chain electrophoresis on acrylamide gels at acid $\mathrm{pH}$ (9). $\mathrm{Hb} \mathrm{A}_{2}$ was measured spectrophotometrically after elution from cellulose acetate strips (1) and $\mathrm{Hb} \mathrm{F}$ was determined by alkali denaturation (10). The stability of each variant was checked by the n-butanol, isopropanol and heat tests (11). Heinz bodies were investigated by incubation with methyl violet and $\mathrm{Hb} \mathrm{H}$ was demonstrated by incubation with brilliant cresyl blue (11).

DNA was isolated from peripheral blood leukocytes by organic extraction. Direct sequencing was performed with the Sequenase kit version 2.0 (United States Biochemical Corporation, Cleveland, OH, USA), after selective amplification of the $\alpha$-globin genes by the polymerase chain reaction (PCR) (12) and single strand separation with magnetic beads (Dynal Inc., Oslo, Norway). Whenever possible, the mutations were confirmed by sequencing the opposite strand and by familial studies and restriction enzyme analyses.

The most common deletions causing $\alpha$ thalassemia $\left(-\alpha^{3.7},-\alpha^{4.2},--\right.$ MED $,-(\alpha)^{20.5},--$ SEA $)$ were screened by PCR (13-15). The five most frequent non-deletional mutations causing $\alpha$-thalassemia $\left(\alpha^{\mathrm{Hph}} \alpha, \alpha^{\mathrm{Ncol}} \alpha, \alpha \alpha^{\mathrm{NcoI}}\right.$, $\alpha^{\mathrm{I}} \alpha$ and $\alpha^{\mathrm{TSaudi}} \alpha$ ) were investigated with the restriction enzymes $\mathrm{Hph} \mathrm{I}, \mathrm{NcoI}$ and $M s e \mathrm{I}$, respectively $(3,16,17)$ and by specific nested PCR ( $\left.\alpha^{\text {TSaudi }}\right)(18)$.

\section{Results}

Among the seven $\mathrm{Hb} \mathrm{H}$ disease patients, all of Italian descent, four had the following genotypes: $-(\alpha)^{20.5 /-\alpha^{3.7}}$ (two cases), --MED/ $-\alpha^{3.7}$ and $-\mathrm{MED}^{\mathrm{MED}} / \alpha^{\mathrm{Hph}} \alpha$. The other three had an unusual unidentified form of $\alpha$-thalassemia which seemed to be non-deletional $\left[-\alpha^{3.7} /(\alpha \alpha)^{\mathrm{T}}\right]$ since both genes were present. No mutation was detected following sequencing from the promoter region to the poly A signal. These results are shown in Table 1.

Among the 27 individuals with structural alterations, 15 (Caucasians of Italian descent) had Hb Hasharon ( $\alpha 47$ Asp $\rightarrow$ His), associated with the $-\alpha^{3.7}$ deletion $\left(-\alpha^{\text {Hasharon }}\right)$ : one was homozygous ( $\left.-\alpha^{\text {Hasharon}} /-\alpha^{\text {Hasharon }}\right)$ and 14 were heterozygous $\left(-\alpha^{\text {Hasharon}} / \alpha \alpha\right)$. One of 
these 14 individuals had a concomitant new B-globin variant, $\mathrm{Hb}$ Rio Claro (B34Val $\rightarrow$ Met) (19). Four adults (Caucasians of Italian descent) were heterozygous for $\mathrm{Hb} \mathrm{J}$-Rovigo $(\alpha 53 \mathrm{Ala} \rightarrow$ Asp) and one of them was also a $\beta$-thalassemia carrier. Hb Stanleyville-II ( $\alpha 78$ Asn $\rightarrow$ Lys) was found in four individuals (3 Blacks and 1 Caucasian, all heterozygous), always in association with the $-\alpha^{3.7}$ deletion $\left(-\alpha^{\text {Stanleyville }}\right)$. One Black infant from the north of Brazil had Hb G-Pest ( $\alpha 74$ Asp $\rightarrow$ Asn), a very rare $\mathrm{Hb}$ described initially in a Hungarian family (20). One boy of Portuguese de- scent had Hb Kurosaki ( $\alpha$ 7Lys $\rightarrow$ Glu), another very rare $\mathrm{Hb}$ described only once in a Japanese woman (21). Hb Westmead ( $\alpha 122$ His $\rightarrow$ Gln), a relatively common silent variant in southern China $(22,23)$, was found in a Caucasian adult of Italian descent. $\mathrm{Hb}$ Campinas ( $\alpha 26 \mathrm{Ala} \rightarrow \mathrm{Val})$ was identified in a Caucasian boy whose ethnic origin was unknown. This electrophoretically silent variant, not described previously, results from a base substitution at the 26th codon of the $\alpha_{2}$ gene (GCG $\rightarrow$ GTG) (24). These structural alterations are summarized in Table 2.

Table 1 - Hematological data for the patients with $\mathrm{Hb} \mathrm{H}$ disease.

RBC, Red blood cells; MCV, mean corpuscular volume; $\mathrm{MCH}$, mean corpuscular hemoglobin.

\begin{tabular}{|c|c|c|c|c|c|c|c|}
\hline Carrier & BFB & FP & EFF & TCA & $\mathrm{CAB}$ & FAF & FVS \\
\hline Age (year) & 40 & 44 & 9 & 7 & 16 & 39 & 6 \\
\hline $\mathrm{RBC}\left(\times 10^{6} / \mathrm{ml}\right)$ & 5.64 & 6.0 & 5.92 & 4.63 & 5.02 & 6.24 & 4.67 \\
\hline $\mathrm{Hb}(\mathrm{g} / \mathrm{dl})$ & 9.7 & 12.1 & 9.0 & 8.3 & 9.4 & 12.6 & 7.9 \\
\hline Hematocrit (\%) & 32.5 & 43 & 33 & 29 & 31 & 42 & 26.5 \\
\hline MCV (fl) & 58 & 69.9 & 55.5 & 63 & 62 & 67 & 57 \\
\hline $\mathrm{MCH}(\mathrm{pg})$ & 17.2 & 19.8 & 15.2 & 17.9 & 18.6 & 20.1 & 16.9 \\
\hline $\begin{array}{l}\text { Electrophoretic } \\
\text { profile (pH 8.9) }\end{array}$ & $\mathrm{A}_{2}+\mathrm{A}+\mathrm{H}$ & $\mathrm{A}_{2}+\mathrm{A}+\mathrm{H}$ & $A_{2}+A+H+$ Bart's & $\mathrm{A}_{2}+\mathrm{A}+\mathrm{H}$ & $A_{2}+A+H+$ Bart's & $\mathrm{A}_{2}+\mathrm{A}+\mathrm{H}$ & $A_{2}+A+H$ \\
\hline $\mathrm{Hb} \mathrm{A}(\%)$ & 1.0 & 1.0 & 1.4 & 0.7 & 1.3 & 1.2 & 0.9 \\
\hline $\mathrm{Hb} F(\%)$ & 1.3 & 1.0 & 1.4 & 0.9 & 1.0 & 1.3 & 1.0 \\
\hline $\mathrm{Hb} H(\%)$ (+ Bart's) & $\begin{array}{c}4.9 \\
20.5 /-\rho^{3} .7\end{array}$ & $\begin{array}{c}6.1 \\
20.5 /-\alpha^{3} .7\end{array}$ & $\begin{array}{c}3.6 \\
\end{array}$ & $\begin{array}{c}26.5 \\
\text { _.MED } / \alpha \mathrm{Hph}_{\alpha}\end{array}$ & $\begin{array}{c}4.5 \\
3.7 /(\alpha \alpha)^{\top}\end{array}$ & $\begin{array}{c}4.5 \\
3.7 /(\alpha \alpha)^{\top}\end{array}$ & $\begin{array}{c}14.0 \\
3.7 /(\alpha \alpha)^{\top}\end{array}$ \\
\hline
\end{tabular}

Table 2 - Structural alterations in $\alpha$-globin genes.

\begin{tabular}{|c|c|c|c|c|c|c|c|}
\hline $\begin{array}{l}\text { Abnormal } \\
\text { hemoglobin }\end{array}$ & $\begin{array}{l}\text { Hasharon } \\
(\alpha 47 \mathrm{Asp} \rightarrow \mathrm{His})\end{array}$ & $\begin{array}{l}\text { Stanleyville-II } \\
\text { ( } \alpha 78 \text { Asn } \rightarrow \text { Lys) }\end{array}$ & $\begin{array}{l}\text { J -Rovigo } \\
(\alpha 53 \text { Ala } \rightarrow \text { Asp })\end{array}$ & $\begin{array}{l}\text { G-Pest } \\
(\alpha 74 \mathrm{Asp} \rightarrow \text { Asn })\end{array}$ & $\begin{array}{l}\text { Kurosaki } \\
(\alpha 7 \text { Lys } \rightarrow \text { Glu) }\end{array}$ & $\begin{array}{l}\text { Westmead } \\
(\alpha 122 \mathrm{His} \rightarrow \mathrm{Gln})\end{array}$ & $\begin{array}{l}\text { Campinas } \\
(\alpha 26 \mathrm{Ala} \rightarrow \text { Val })\end{array}$ \\
\hline $\begin{array}{l}\text { No. of } \\
\text { individuals }\end{array}$ & 15 & 4 & 4 & 1 & 1 & 1 & 1 \\
\hline Race & Caucasians & $\begin{array}{l}3 \text { Blacks + } 1 \\
\text { Caucasian }\end{array}$ & Caucasians & Black & Caucasian & Caucasian & Caucasian \\
\hline $\begin{array}{l}\text { Electrophoretic } \\
\text { profile (pH 8.9) }\end{array}$ & $A_{2}^{\prime}, A_{2}$, Hash.,A & $\mathrm{A}_{2}{ }^{\prime}, \mathrm{A}_{2}, \mathrm{Stanl}, \mathrm{A}$ & $A_{2}, A, J$-Rovigo & $A_{2}{ }^{\prime}, A_{2}, G-P e s t, A$ & $\mathrm{~A}_{2}, \mathrm{~A}$, Kurosaki & $\mathrm{A}_{2} \mathrm{~A}$ & $\mathrm{~A}_{2} \mathrm{~A}$ \\
\hline $\begin{array}{l}\text { Globin } \\
\text { electrophoresis }\end{array}$ & $\alpha+\alpha^{H}+\beta$ & $\alpha+\beta$ & $\alpha+\beta$ & $\alpha+\beta$ & $\alpha+\alpha^{K}+\beta$ & $\alpha+\beta+\alpha W$ & $\alpha+\alpha C+\beta$ \\
\hline$\alpha$-Genotype & $-\alpha^{3.7 / \alpha \alpha}$ & $-\alpha^{3.7} / \alpha \alpha$ & $\alpha \alpha / \alpha \alpha$ & $\alpha \alpha / \alpha \alpha$ & $\alpha \alpha / \alpha \alpha$ & $\alpha \alpha / \alpha \alpha$ & $\alpha \alpha / \alpha \alpha$ \\
\hline Mutation & $\alpha_{1}(\mathrm{GAC} \rightarrow \underline{\mathrm{CAC}})$ & $\alpha_{1}(\mathrm{AAC} \rightarrow \mathrm{AAA})$ & $\alpha_{2}(\mathrm{GCC} \rightarrow \mathrm{GAC})$ & $\alpha_{2}(\mathbf{G A C} \rightarrow \underline{\mathbf{A} A C})$ & $\alpha_{1}(\mathbf{A} A G \rightarrow \underline{G} A G)$ & $\alpha_{2}(\mathrm{CAC} \rightarrow \mathrm{CAG})$ & $\alpha_{2}(\mathrm{GCG} \rightarrow \mathrm{GTG})$ \\
\hline
\end{tabular}




\section{Discussion}

The thalassemic mutations found in four of the seven $\mathrm{Hb} \mathrm{H}$ disease patients $\left(-\alpha^{3.7},--{ }^{M E D},-(\alpha)^{20.5}\right.$ and $\left.\alpha^{\mathrm{Hph}} \alpha\right)$ are the most frequent in Mediterranean populations: the first three are common deletions which remove 3.7-, 18- and 20.5-kb fragments of DNA from the $\alpha$-globin gene cluster, respectively, and the latter is a common nondeletional form which removes five nucleotides from the consensus sequence of the splicing donor site of IVS-I (3). All of the $\mathrm{Hb}$ $\mathrm{H}$ disease patients were of Italian descent. In contrast, the remaining three patients showed the association of the $-\alpha^{3.7}$ deletion with an unusual form of $\alpha$-thalassemia which leaves both $\alpha$-genes intact, but without expression. This situation may result from an alteration in the $\alpha$-major regulatory element $(\alpha-\mathrm{MRE}$ or HS-40), a major positive regulatory region located $40 \mathrm{~kb}$ upstream of the $\xi_{2}$-globin gene cap site (25). A few large deletions are known to remove this locus control region and thereby silence the $\alpha$-globin genes, which remain structurally intact (3).

Among the structural alterations, $\mathrm{Hb}$ Hasharon, the most frequent change, and $\mathrm{Hb}$ J-Rovigo, are of Italian origin, whereas $\mathrm{Hb}$ Stanleyville-II is of African origin and Hb GPest was first described in a Hungarian family in 1972 (20). The last one was found here for the first time in the Brazilian population. $\mathrm{Hb}$ Kurosaki was initially described in a 70year-old Japanese woman (21), being the case described here the second reported in the world and the first one in Brazil. $\mathrm{Hb}$
Westmead was discovered in a Chinese female in 1980 (23) and is common in Guangxi, a province in southern China (22). In the case described here, the first in Brazil, the carrier was of Italian descent. Hbs G-Pest, Kurosaki and Westmead were detected in a screening program, but in carriers with ethnic origins different from those of the original descriptions, suggesting de novo mutations. Hb Campinas was a novel silent variant encountered in a Caucasian boy of unknown descent (24).

Clinically and hematologically, Hbs JRovigo, G-Pest, Kurosaki, Westmead and Campinas caused no abnormalities, since the carriers were asymptomatic. Hb Hasharon and $\mathrm{Hb}$ Stanleyville-II carriers had mild microcytic and hypochromic red blood cells, probably because of the association with $\alpha$ thalassemia.

The present study on 34 persons represents the most extensive analysis to-date of individuals with $\alpha$-globin gene mutations in Brazil. The results confirmed the strong Italian and African influences in the region of Brazil examined, and reflected the intense immigration that took place in the last century and at the beginning of the twentieth century.

\section{Acknowledgments}

We thank Dr. Stephen Hyslop, Department of Pharmacology, School of Medical Sciences, UNICAMP, for reviewing the language of the manuscript.

\section{References}

1. Weatherall DJ \& Clegg JG (1981). The Thalassaemia Syndromes. 3rd edn. Blackwell Scientific Publications, Oxford.

2. Bunn HF \& Forget BG (1986). Hemoglobin: Molecular, Genetics and Clinical Aspects. W.B. Saunders, Philadelphia.

3. Kattamis AC, Camaschella C, Sivera P, Surrey S \& Fortina P (1996). Human $\alpha$ - thalassemia syndromes: detection of molecular defects. American J oumal of Hematology, 53: 81-91.

4. Working Party of the General Haematology Task Force of the British Committee for Standards in Haematology (1998). Guideline. The laboratory diagnosis of haemoglobinopathies. British J ournal of
Haematology, 101: 783-792.

5. Zago MA \& Costa FF (1985). Hereditary haemoglobin disorders in Brazil. Transaction of the Royal Society of Tropical Medicine and Hygiene, 79: 385-388.

6. Sonati MF, Kimura EM, Grotto HZW, Gervásio SA \& Costa FF (1996). Hereditary hemoglobinopathies in a population 
from southeast Brazil. Hemoglobin, 20: 175-179.

7. Sonati MF, Farah SB, Ramalho AS \& Costa FF (1991). High prevalence of $\alpha$-thalassemia in a Black population of Brazil. Hemoglobin, 15: 309-311.

8. Zago MA, Costa FF \& Bottura C (1984). Hemoglobin $\mathrm{H}$ disease in three Brazilian families. Revista Brasileira de Genética, VII: 137-147.

9. Alter BP, Goff SC, Efremov GD, Gravely ME \& Huisman THJ (1980). Globin chain electrophoresis: a new approach to the determination of the $\gamma^{G} \gamma^{A}$ ratio of globin synthesis. British J oumal of Haematology, 44: 527-534.

10. Pembrey ME, MacWade $P \&$ Weatherall DJ (1972). Reliable routine estimation of small amounts of foetal haemoglobin by alkali denaturation. J ournal of Clinical Pathology, 25: 738-740.

11. Dacie JV \& Lewis SM (1995). Practical Haematology. 8th edn. Churchill Livingstone, Edinburgh.

12. Dodé C, Rochette J \& Krishnamoorthy R (1990). Locus assignment of human $\alpha$ mutation by selective amplification and direct sequencing. British J ournal of Haematology, 76: 275-281.

13. Baysal E \& Huisman THJ (1994). Detection of common deletional $\alpha$-thalassemia2 determinants by PCR. American J ournal of Hematology, 46: 208-213.

14. Bowden DK, Vickers MA \& Higgs DR
(1992). A PCR-based strategy to detect the common severe determinants of $\alpha$ thalassaemia. British J ournal of Haematology, 81: 104-108.

15. Dodé C, Krishnamoorthy R, Lamb J \& Rochette J (1993). Rapid analysis of $-\alpha^{3.7}$ thalassaemia and $\alpha \alpha \alpha^{\text {anti }} 3.7$ triplication by enzymatic amplification analysis. British J ournal of Haematology, 82: 105-111.

16. Traeger-Synodinos J, Kanavakis E, Tzetis M, Kattamis A \& Kattamis C (1993). Characterization of nondeletional $\alpha$ thalassemia mutations in the Greek population. American J ournal of Hematology, 44: 162167.

17. Makonkawkeyoon L, Sanguansermsri T, Asato T, Nakashima Y \& Takei H (1993). Rapid detection of chain termination mutation in the $\alpha_{2}$ globin gene. Blood, 82: 3503-3504.

18. Hall GW, Thein SL, Newland CA, Chisholm J TS, Kanavakis E, Kattamis C \& Higgs DR (1983). A base substitution $(T \rightarrow C)$ in codon 29 of the $\alpha_{2}$-globin gene causes $\alpha$ thalassemia. British J ournal of Haematology, 85: 546-552.

19. Grignoli CRE, Wenning MRSC, Sonati MF, Kimura EM, Amuda VR, Saad STO \& Costa FF (1999). Hb Rio Claro B34 (B16) Val $\rightarrow$ Met: a novel electrophoretically silent variant found in association with $\mathrm{Hb}$ Hasharon $\alpha 47$ (CE5) Asp $\rightarrow$ His and $\alpha$ thalassemia $2\left(-\alpha^{3.7}\right)$. Hemoglobin, 23: 177-182.
20. Brimhall B, Durest M, Hollan SR, Stenzel P, Szelènyl J \& J ones RT (1974). Structural characterization of hemoglobin J Buda [ $\alpha 61($ E10) Lys $\rightarrow$ Asn] and G-Pest $[\alpha 74(E F 3)$ Asp $\rightarrow$ Asn]. Biochimica et Biophysica Acta, 336: 344-360.

21. Harano T, Harano K, Imai K, Murakami T \& Matsubara H (1995). Hb Kurosaki [ $\alpha$ 7(A5) Lys $\rightarrow$ Glu]: a new $\alpha$ chain variant found in a apanese woman. Hemoglobin, 19: 197201.

22. J iang $\mathrm{NH}$, Liang $\mathrm{S}$, Wen $\mathrm{XJ}$, Liang $\mathrm{R}$, Su $\mathrm{C}$ \& Tang Z (1991). Hb Westmead: an $\alpha 2$ globin gene mutation detected by polymerase chain reaction and Stul cleavage. Hemoglobin, 15: 291-295.

23. Gu Y-C, Gu L-H, Wilson J B, Cepreganova B, Ramachandran M, Walker ELD \& Huisman THJ (1991). Hb Westmead $[\alpha 122(\mathrm{H} 5) \mathrm{His} \rightarrow \mathrm{GIn}], \mathrm{Hb}$ E [B26(B8) Glu $\rightarrow$ Lys], and $\alpha$-thalassemia-2 (3.7 kb deletion) in a Laotian family. Hemoglobin, 15: 297-302.

24. Wenning MRSC, Silva NM, J orge SB, Kimura EM, Costa FF, Torsoni MA, Ogo SH \& Sonati MF (2000). Hb Campinas [ $\alpha$ 26(B7)Ala $\rightarrow$ Val]: a novel, electrophoretically silent, variant. Hemoglobin, 24: 143148.

25. Higgs DR, Wood WG, J arman AP, Sharpe J , Pretorius IM \& Ayyub H (1990). A major positive regulatory region located far upstream of the human $\alpha$-globin gene locus. Genes and Development, 4: 1588-1601. 